\title{
PERAN BIDANG HUBUNGAN MASYARAKAT KEPOLISIAN DAERAH DAERAH ISTIMEWA YOGYAKARTA DALAM MANAJEMEN KOMUNIKASI PUBLIK
}

\author{
Oleh: \\ Medi Trilaksono Dwi Abadi \\ Dosen Program Studi Sarjana Ilmu Komunikasi \\ Universitas 'Aisyiyah Yogyakarta \\ E-mail: meditrilaksono@unisayogya.ac.id
}

\begin{abstract}
Abstrak
Kepolisian merupakan organisasi pemerintah yang fungsinya adalah sebagai pelindung, pengayom, dan pelayan masyarakat di Indonesia. Peran polisi sangat berat dalam melaksanakan fungsinya tersebut, mengingat pelanggaran hukum yang ditangani oleh polisi dari waktu ke waktu semakin meningkat. Dalam kondisi tersebut. Profesionalitas polisi harus lebih ditingkatkan demi menjaga nama baik polisi di mata masyarakat. Banyaknya komitmen pemerintah untuk lebih menstabilkan kondisi bangsa Indonesia berbagai masalah pelanggaran hukum, seperti pembasmian terorisme, ungkap kasus narkoba, penangkapan buronan, dan lain sebagainya, serta peningkatan keamanan dan ketertiban masyarakat yang merupakan bagian penting dari stabilitas politik adalah bentuk tanggungjawab polisi untuk pemerintah yang harus dijalankan dengan baik. Sebagai pendukung yang berfungsi menjadi jembatan penghubung antara kepolisian dengan khalayak luas maka dibentuk satuan kerja yang khusus menangani hubungan masyarakat yang disebut Bidang Hubungan Masyarakat (Bidhumas). Kinerja kepolisian dibagi menjadi beberapa wilayah hukum yaitu dari tingkat tertinggi Mabes Polri, Polda, Polres,d an Polsek. Penelitian ini bertujuan untuk menganalisa proses pengelolaan informasi yang dilakukan Bidhumas Polda DIY yang berkaitan dengan manajemen komunikasi publik. Peran Bidhumas Polda DIY dalam proses pengelolaan informasi dan manajemen komunikasi menjadi fokus utama dalam penelitian ini. Penelitian ini mengambil lokasi di wilayah Propinsi Daerah Istimewa Yogyakarta, maka penelitian ini menunjuk Polda DIY melalui satuan kerja Bidhumas sebagai subjek penelitian yang menjadi jembatan penghubung utama antara Polda DIY dengan masyarakat umum DIY dalam mengelola interaksi dan berkomunikasi. Penelitian ini menggunakan metode analisis deskriptif kualitatif. Teknik wawancara dan observasi langsung digunakan untuk mendapatkan kesesuaian data antara informan dan objek penelitian. Hasil penelitian ini menunjukkan bahwa Bidhumas Polda DIY dalam mengelola informasi terkait proses manajemen komunikasi publik dengan cara memanfaatkan media. Media yang dimaksud adalah media sebagai alat bantu penyebar informasi dan media sebagai lembaga yang mengelola informasi yaitu media pemberitaan. Media sebagai alat bantu oleh Bidhumas Polda DIY dibedakan menjadi dua yaitu media konvensional: media cetak dan media elektronik, serta yang kedua adalah media baru yaitu media yang berbasis pada teknologi internet yang mengutamakan kecepatan dan jangkauan luas dalam penyebaran informasi.
\end{abstract}

Kata kunci: manajemen komunikasi, peran humas, pemanfaatan media.

\begin{abstract}
In Indonesia, Police is a government organization whose function is as patron, protector, and public servant. The police role is very heavy in carrying out its function, considering the violation of law handled by the police from time to time increasing. Under these conditions, the professionalism of the police should be further enhanced in order to maintain the police's credibility in the public. The number of government commitments to further stabilize the condition of the Indonesian nation various legal problems, such as the eradication of terrorism, drug cases, fugitive
\end{abstract}


arrests, etc., and the improvement of public order and security which is an important part of political stability is a form of police responsibility for the government which must well executed. As a supporter who serves as a bridge between the police with a wide audience then formed a work unit that specifically handles public relations called the Field of Public Relations (Bidhumas). Police performance is divided into several jurisdictions, namely from the highest level of Police Headquarters, Police, Polres, and Polsek. This study aims to analyze the information management process conducted by Bidhumas Polda DIY related to the management of public communication. The role of Bidhumas Polda DIY in the process of information management and communication management became the main focus in this research. This research takes place in the region of Yogyakarta Special Province, hence this research appoint Polda DIY through work unit of Bidhumas as research subject becoming the main bridge between Polda DIY with DIY public in managing interaction and communicate. This research uses descriptive qualitative analysis method. Interview techniques and direct observation are used to obtain data suitability between informants and research objects. The results of this study indicate that Bidhumas Polda DIY in managing information related to public communication management process by utilizing media. Media in this case is the media as a tool to spread information and media as an institution that manages information such as news media. Media as a tool by Bidhumas Polda DIY is divided into two conventional media: print media and electronic media, and the second is a new media that is based on internet technology that prioritizes speed and wide range in the dissemination of information.

Keywords: communication management, public relations roles, media utilization.

\section{A. PENDAHULUAN}

Kepolisian merupakan organisasi pemerintah yang salah satu fungsinya adalah sebagai pelindung dan pelayan masyarakat Indonesia. Peran polisi sangat berat dalam melaksanakan fungsinya tersebut mengingat pelanggaran-pelanggaran hukum yang ditangani oleh polisi dari waktu kewaktu semakin meningkat. Dalam kondisi tersebut profesionalitas polisi harus lebih ditingkatkan demi menjaga nama baik Polisi di mata masyarakat. Mengingat banyaknya komitmen pemerintah untuk lebih menstabilkan kondisi Bangsa Indonesia dalam berbagai masalah pelanggaran hukum seperti pembasmian terorisme, penangkapan para koruptor, serta peningkatan keamanan masyarakat yang merupakan bagian penting dari stabilitas politik adalah bentuk tanggungjawab Polisi untuk pemerintah yang harus dijalankan dengan baik.

Sesungguhnya permasalahan penegakan hukum bukanlah hal baru bagi polisi, karena selama ini polisi telah berusaha menjalankan fungsinya. Diharapkan adanya kerjasama yang baik antara polisi dan masyarakat tentang masalah penegakan hukum. Tanpa adanya bentuk kerjasama dari keduanya persoalan penegakan hukum menjadi lebih sulit teratasi, karena itu diperlukan adanya rasa saling mempercayai diantara dua pihak, baik dari Polisi maupun masyarakat sekitar. Namun tingkat kepercayaan masyarakat pada polisi semakin lama semakin berkurang disebabkan adanya persepsi negatif masyarakat pada tubuh polisi. Citra baik polisi di mata masyarakat seringkali dikotori oleh ulah oknumnya sendiri sehingga polisi didera vonis yang negatif, sebagai contoh: kasus pembunuhan wartawan Udin yang sudah lama bergulir tapi sampai saat ini belum tuntas proses penyelidikan dan investigasinya. Seringkali masyarakat membuat stereotipe masalah yang ada, kesalahan pada salah satu oknum polisi tapi kemudian masyarakat menilai hal itu merupakan kesalahan dalam tubuh organisasi Polisi secara keseluruhan.

Beberapa kasus yang seringkali menjadi masalah adalah kasus penyalahgunaan wewenang, penganiayaan, ketidak jelasan dalam penyampaian informasi suatu kasus, 
pelecehan seksual, perbuatan tidak menyenangkan, pengusutan kasus yang tidak kunjung selesai, dan penyalahgunaan senjata api. Kasus tersebut perlahan-lahan membentuk sebuah opini negatif dan sikap tidak percaya dalam masyarakat, karena opini yang seharusnya terbentuk adalah polisi merupakan sebuah figur yang patut untuk dicontoh dan diandalkan, karena kekuatan polisi merupakan pilar utama dalam masalah keamanan dan ketertiban masyarakat. Sehingga dalam menjalankan fungsinya seringkali publik atau masyarakat meragukan kemampuan polisi dalam menjalankan fungsinya sebagai pelindung dan penganyom yang dapat dipercaya.

Anggota dari Polisi merupakan anggota masyarakat juga. Keberadaan polisi sangat erat kaitannya dengan masyarakat, karena masyarakat yang memiliki pengaruh paling besar dan merupakan target utama dalam memberikan pelayanan kepada mereka. Oleh karena itu dibutuhkan peran aparat keamanan. Untuk menjaga keamanan dan ketertiban dalam masyarakat. Kepolisian Daerah Istimewa Yogyakarta (Polda DIY) dibentuk sebagai alat negara yang berperan dalam memelihara keamanan dan ketertiban masyarakat (kamtibnas), penegak hukum (gakkkum) serta memberikan perlindungan, pengayoman dan pelayanan bagi masyarakat dalam rangka terciptanya keamanan dalam di Daerah Istimewa Yogyakarta.

Keterbukaan informasi merupakan salah satu pilar penting untuk mendorong terciptanya iklim keterbukaan dalam pelaksanaan tata pemerintahan yang baik (good governance). Dengan diberlakukannnya Undang-undang 14 Tahun 2008 tentang Keterbukaan Informasi Publik, sejak 1 Mei 2010 pemerintah sebagai penyelenggara program pembangunan dan pelayanan publik wajib membuka akses layanan informasi kepada masyarakat. Undang-undang Keterbukaan Informasi Publik diatur mengenai kewajiban badan publik negara dan badan publik non negara untuk memberikan pelayanan informasi secara terbuka, transparan dan bertanggung jawab kepada masyarakat. Berdasarkan Undang- undang, semua lembaga publik berkewajiban membuka akses atas informasi secara wajar terhadap publik. Semua perangkat pemerintah termasuk kepolisian harus siap untuk membuka akses informasi seluas-luasnya bagi masyarakat.

Saat ini humas kepolisian harus mengubah paradigma kehumasannya. Humas bukan lagi sebagai lembaga yang melakukan sensor berita dan anti kritik. Tapi, humas harus menganut prinsip keterbukaan yang mampu membangun hubungan yang harmonis dengan masyarakat. Berhubungan dengan masyarakat, baik secara personal ataupun melalui forum diskusi adalah cara mewujudkan komunikasi yang bersifat terbuka.

Akibatnya, banyak pekerjaan polisi yang semestinya bisa diselesaikan dengan melibatkan partisipasi masyarakat, namun masyarakat kurang memberikan informasi secara lengkap. Dengan demikian, polisi harus mengedepankan pendekatan humanis dalam setiap menangani persoalan kamtibmas. Sebagai gantinya, penyelesaian persoalan kamtibmas dengan pedoman menghargai hak asasi manusia (HAM) perlu dikedepankan. Melalui cara demikian, otomatis kedekatan Polisi dan masyarakat dapat tercipta. Selanjutnya, harapan Polisi dengan terbentuknya kemitraan dan jaringan yang disertai dengan sikap keterbukaan dalam penyampaian informasi, polisi akan dapat pula menciptakan dan membangun citra polisi yang baik. 
Berdasarkan penggambaran fenomena permasalahan diatas, maka penelitian ini rumusan masalahnya adalah Bagaimana peran divisi humas Polda DIY dalam mengelola informasi terkait manajemen komunikasi publik?

Sesuai dengan judul penelitian diatas, maka penelitian ini bertujuan untuk:

1. Mengetahui proses pengelolaan informasi yang dilakukan Polda DIY.

2. Mengetahui peran divisi humas Polda DIY dalam menjalani tugasnya di kepolisian.

\section{B. TINJAUAN PUSTAKA}

Kerangka teori adalah berupa uraian tentang dasar teori atau model yang digunakan sebagai acuan penelitian. Setiap penelitian selalu menggunakan teori. Berdasarkan teori yang pernah diperoleh suatu kerangka analisis untuk menerangkan hasil penemuannya. Dengan teori pula dapat memungkinkan seseorang menghubungkan data-data yang sebenarnya mempunyai kaitan satu sama lain. Dalam penelitian ini, penulis menggunakan teori yang tentunya terkait dengan masalah penelitian yang ingin diteliti oleh penulis, teori tersebut adalah:

1. Definisi Humas / Public Relations

Public relations adalah fungsi manajemen yang membangun dan mempertahankan hubungan yang baik dan bermanfaat antara organisasi dengan publik yang mempengaruhi kesuksesan atau kegagalan organisasi tersebut (Cutlip, Center, Broom, 2011:6). Public relations sebagai sebuah fungsi manajemen, yang berarti bahwa manajemen di semua organisasi harus memperhatikan public relations. Menurut Harlow, Public Relations adalah fungsi manajemen yang membantu mendirikan dan memelihara hubungan komunikasi yang saling menguntungkan, keterbukaan dan kerjasama antara organisasi dan publiknya, melibatkan manajemen masalah dan isu, membantu manajemen untuk tetap terinfomasi dan responsive terhadap publik. Menurut Jefkins (2003: 10), public relations adalah semua bentuk komunikasi yang terencana, baik yang sifatnya internal (ke dalam) maupun yang sifatnya eksternal (ke luar), antara suatu organisasi dengan semua khalayaknya dalam rangka mencapai tujuan-tujuan spesifik yangberlandaskan pada saling pengertian. Teori tentang public relations sebagai fungsi manajemen dipilih karena dalam organisasi kepolisian yaitu Polda DIY tentunya membutuhkan strategi yang tepat untuk mengelola segala bentuk pesan dan informasi yang ada. Polda DIY melalui divisi humasnya tentunya memiliki kebijakan pertimbangan yang sudah disesuaikan dengan kepentingan keterbukaan informasi yang akan dipublikasikan kepada publik Polda DIY yaitu masyarakat Yogyakarta. Hal utama yang mendasari adalah tidak semua pesan ataupun informasi yang dimiliki Polda DIY harus dipublikasikan kepada khalayak Yogyakarta. Polda DIY memilah pesan atau informasi yang mana yang layak dikonsumsi khalayak Yogyakarta mana yang tidak.

Peran Humas / Public Relations

Peran adalah seperangkat tingkah laku yang diharapkan oleh orang lain terhadap seseorang sesuai kedudukannya dalam, suatu system. Peran profesi public relations semakin bias tanpa adanya spesialisasi profesi sehinggadiharapkan seorang praktisi PR memahami perannya dengan baik. Ada beberapa fungsi dominan yang harus dilaksanakan 
seorang praktisi PR, antara lain seperti yang dirumuskan oleh Cutlip, Center, dan Broom 2011: 46, yaitu:

- Teknisi komunikasi (Communication Technician)

- Pakar perumus komunikasi (Expert Prescriber Communication)

- Fasilitator komunikasi (Communication Facilitator)

- Pemecah masalah (Problem Solver)

Banyak faktor yang mempengaruhi peran praktisi public relations antara lain : pendidikan, pengalaman professional, kepribadian, supervisi, serta kultur dan lingkungan organisasional. Praktisi yang memahami sebab dan akibat dari melakukan peran yang berbeda-beda dapat mengembangkan strategi untuk menghadapi berbagai situasi dan pandangan peran praktisi lainnya. Pemahaman ini mungkin penting bagi wanita karena adanya perbedaan peran yang disebabkan oleh gaji dan partisipasi dalam pembuatan keputusan manajemen. Dalam hal ini, sesuai dengan kondisi organisasi Polda DIY yang mana kepala divisi humasnya juga seorang wanita. Public relations dalam fungsi organisasi berperan sebagai media relation, customer relation, community relation. Fungsi public relations adalah sebagai berikut:

1. Manajemen Berita :

- Mengkreasikan dan mendistribusikan pesan untuk membangun publisitas yang menguntungkan.

- Membangun dan memelihara kontrak dengan wartawan.

2. Hubungan Komunitas :

- Memelihara hubungan yang baik dengan pemerintah dan kelompok komunitas.

- Menggunakan bantuan dan sponsor korporat.

- Memberikan kontribusi yang bersifat amal pada tingkat lokal dan nasional.

3. Manajemen Krisis :

- Memberikan citra klien di mata public karena perselisihan internal, kesalahan kebijakan atau kecelakaan yang tak disengaja.

- Memberi pedoman bagi korporat dalam merespons pada keadaan mendesak.

- Memulihkan citra di mata public yang menyertai suatu konflik atau krisis.

4. Lobi

- Memonitor aktivitas pemerintah.

- Memelihara hubungan dengan legislator.

- Menyebarkan informasi kepada legislator untuk mendukung hukum atau kebijakan yang menguntungkan klien.

- Mempengaruhi voting legislator melalui hubungan atau kontrol pribadi.

3. Manajemen Komunikasi

Manajemen komunikasi menurut (Kaye, 1994: 9) kelahiran sub-disiplin manajemen komunikasi tidak terlepas dari adanya tuntutan untuk lebih membumikan ilmu komunikasi di tataran dunia nyata. Menurut Cutlip Center Broom, manajemen komunikasi adalah proses timbal balik pertukaran sinyal untuk memberi informasi, membujuk atau 
memberi perintah, berdasarkan makna yang sama dan dikondisikan oleh konteks hubungan para para komunikator dan konteks sosialnya.

Manajemen komunikasi dalam penelitian ini adalah proses perencanaan, pengorganisasian, pelaksanaan, kontrol, dan evaluasi dari suatu pesan atau informasi yang ada yang akan disampaikan kepada penerima pesan atau informasi tersebut. Rangkaian proses manajemen komunikasi ini dilakukan pada dua lingkup yaitu: eksternal dan internal. Lingkup eksternal adalah pemangku kepentingan yang ada diluar lingkungan Polda DIY atau pihak yang memiliki kepentingan dengan Polda DIY tetapi yang bukan termasuk anggota atau jajaran Polda DIY. Sedangkan lingkup internal adalah pihak yang memiliki kepentingan yang terkait langsung dengan Polda DIY yaitu anggota Polda DIY beserta seluruh jajarannya di wilayah Propinsi Daerah Istimewa Yogyakarta.

Berdasarkan uraian diatas, maka konsep penelitian ini memposisikan Polda DIY sebagai organisasi keamanan negara di tingkat daerah yang harus menyelaraskan visi, misi, dan kinerjanya dengan situasi dan kondisi yang ada di masyarakat Propinsi Daerah Istimewa Yogyakarta berdasarkan teori manajemen komunikasi, maka Polda DIY dituntut masyarakat DIY untuk mampu menjawab pertanyaan-pertanyaan yang muncul dari masyarakat seputar kasus-kasus yang terjadi di wilayah Daerah Istimewa Yogyakarta. Masyarakat DIY menginginkan adanya keterbukaan informasi dari pihak Polda DIY terkait kasus-kasus yang terjadi di DIY, selain itu masyarakat DIY juga menginginkan adanya ketegasan dan kejelasan dari pihak Polda DIY dalam menangani kasus-kasus yang terjadi di wilayah DIY. Masyarakat DIY tidak ingin memperoleh informasi hanya sebatas jawaban yang dianggap jawaban umum seperti pada ungkapan yang sering disampaikan pihak Polda DIY kepada masyarakat umum yaitu "kasus ini masih ditangani pihak kami, kelanjutannya bagaimana nanti kami sampaikan perkembangannya".

Masyarakat DIY adalah publik eksternal yang mana ada yang aktif menuntut keterbukaan informasi dan ada yang pasif menunggu publikasi informasi dari pihak Polda DIY. Namun demikian, dalam penelitian ini titik tekannya ada pada keselarasan penyampaian informasi dan penyampaian respon antara kedua pihak yaitu Polda DIY dan masyarakat DIY. Penelitian ini ingin mengaplikasikan model komunikasi dua arah yang asimetris, yaitu respon atau timbal balik dari komunikan yaitu masyarakat DIY hanya sebatas bahan pertimbangan sekunder dalam penentuan keputusan publikasi informasi yang akan dilakukan oleh divisi humas Polda DIY.

\section{METODE PENELITIAN}

Penelitian ini merupakan penelitian kualitatif dengan pendekatan deskriptif kualitatif. Pada penelitian ini, setelah peneliti mengumpulkan data dalam bentuk hasil wawancara, dokumentasi, dan observasi maka untuk selanjutnya data tersebut akan dianalisis lebih mendalam lagi sehingga membentuk suatu kesimpulan ilmiah- alamiah yang dapat diterima oleh berbagai kalangan, terutama dalam hal ini adalah kepolisian daerah istimewa Yogyakarta sebagai subyek penelitian dalam tesis. Kepolisian Daerah Daerah Istimewa Yogyakarta memiliki lokasi kantor yang beralamatkan di Jl. Ring road Utara Condong Catur, Depok, Sleman. Subjek utama penelitian ini adalah Bidang Hubungan Masyarakat (Bidhumas) Polda DIY dengan narasumber utama adalah Kepala 
Bidang Hubungan Masyarakat (KaBidhumas) yaitu Ibu AKBP Hj. Anny Pudjiastuti, S.Sos, M.Si dan didukung oleh narasumber lain yaitu tim bawahan Kabidhumas diberbagai jabatan sesuai dengan struktural Bidhumas Polda DIY. Pemilihan narasumber tersebut bertujuan untuk mewakili baik proses komunikasi, pemahaman serta komitmen di masingmasing jenjang struktural serta masing-masing satuan kerja agar mendapat gambaran yang menyeluruh terkait peran humas di Polda DIY dalam manajemen komunikasi publik.

\section{PEMBAHASAN}

Peran humas yang dilakukan Bidhumas Polda DIY memiliki titik tekan pada pembentukan jalinan hubungan dengan media sebagai institusi pemberitaan, pemanfaatan media sebagai alat bantu untuk mengelola segala informasi yang ada agar mudah disampaikan kepada publik internal dan publik eksternal Polda DIY, serta koordinasi yang berkesinambungan dengan satuan kerja yang lain. Hubungan saling ketergantungan yang bersifat mutualis juga merupakan kunci kelancaran pengelolaan informasi antara Polda DIY melalui Bidhumas dengan publik Polda DIY. Kepolisian butuh untuk mempublikasikan segala informasi yang ingin diketahui berbagai lapisan masyarakat Yogyakarta dari akademisi, lembaga pemerintah, masyarakat umum, dan lain sebagainya.

Namun tidak dipungkiri juga terkadang terjadi hal-hal yang mencoreng nama baik dan kredibilitas Polda DIY dari ulah para anggota dan jajaran Polda DIY yang melakukan tindakan melanggar aturan dan etika disiplin kepolisian atau bahkan ada yang melakukan tindak kriminal. Dengan adanya pemberitaan yang negatif tersebut, Polda DIY juga harus cermat dalam menyikapinya agar bisa mendapatkan kembali simpati dari masyarakat Yogyakarta agar bisa mengembalikan nama baik dan kredibilitas Polda DIY. Oleh karena itu, cara yang dilakukan Polda DIY selain mempublikasikan hal yang berhubungan dengan tindakan kebaikan kepolisian juga sekaligus mempublikasikan informasi mengenai tindakan yang buruk dari kepolisian, seperti mempublikasikan nama-nama anggota dna jajaran Polda DIY yang melakukan tindakan pelanggaran etika dan disiplin kepolisian. Hal ini dilakukan agar masyarakat Yogyakarta juga tahu bahwa Polda DIY tidak hanya mendiamkan anggota dan jajarannya yang melakukan pelanggaran etika dan disiplin tetapi juga menindak tegas mereka. Bentuk tindakan tegas pun disesuaikan dengan tindak pelanggaran yang dilakukan para anggota dan jajaran Polda DIY.

Selain itu, peran humas yang dilakukan Polda DIY adalah bisa dengan menerbitkan laporan atau jurnal sebagai pedoman pegangan bagi publik internal maupun eksternal Polda DIY. Laporan atau jurnal tersebut terbagi menjadi dua yaitu yang diterbitkan setiap bulan sekali dan yang diterbitkan setiap tahun sekali. Laporan atau jurnal yang diterbitkan setiap bulan sekali disebut sebagai majalah Manggala, sedangkan laporan atau jurnal yang terbit setiap tahun sekali disebut Laporan Jumpa Pers Akhir Tahun. Namun demikian, meskipun sudah publik internal dan eksternal Polda DIY sudah diberi pedoman tersebut, kegiatan kehumasan Polda DIY tetap dilakukan karena mereka seringkali dihadapkan pada situasisituasi tertentu yang mengandung propaganda. Sebagai contohnya seringkali Polda DIY dihadapkan pada situasi yang buruk tetapi Polda DIY dituntut harus mampu memberikan penjelasan yang baik dan detil dengan cara yang tepat. 
Contoh peranan teknis kehumasan yang biasa digunakan dalam Polda DIY antara lain adalah: layanan informasi untuk masyarakat umum ataupun kalangan pers, media publikasi internal, pemutaran film dokumenter, pameran, terbuka menerima tamu siapa saja di kantor Polda DIY khususnya di Bidhumas Polda DIY, mengadakan acara talk show di stasiun televisi dengan para pejabat kepolisian dan pakar kriminal, hingga kunjungan Polisi ke sekolah-sekolah untuk memberikan edukasi kepada para pelajar.

Program kehumasan yang menunjang kinerja Polda DIY dalam menjalani tugas sehari-hari adalah selalu mengikuti pimpinan tertinggi yaitu Kapolda DIY kemana pun pergi ataupun saat memberikan keterangan penjelasan kepada para wartawan. Hal ini diistilah oleh Bidhumas Polda DIY dengan istilah melekat pada pimpinan. Hal ini selalu dilakukan hampir setiap hari karena Bidhumas Polda DIY melalui pimpinannya yaitu Kabid Humas selalu berperan menghadapi wartawan dari berbagai media massa cetak maupun elektronik. Tugasnya adalah memberikan tambahan keterangan penjelas kepada para wartawan terkait isu-isu atau kasus yang sedang terjadi di seputaran wilayah Yogyakarta, Kapolda hanya berbicara singkat secara strategis saja. Detil keterangannya secara teknis dilimpahkan kepada Kabid Humas.

Ada beberapa tanggung jawab yang dibebankan kepada petugas humas sebagai tugas tambahan yaitu harus mampu menciptakan penilaian yang positif terhadap Polda DIY dari mata publik internal maupun eksternal, secara umum humas harus mampu mengelola sirkulasi informasi dengan optimal agar masyarakat juga menilai kinerja Polda DIY baik berdasarkan sikap terbuka dalam informasi yang ada. Selain itu juga humas harus mampu mendidik anggota Polda DIY dan seluruh jajarannya untuk bisa bersikap lebih ramah dan menghilangkan kesan sangar arogan kepada masyarakat umum. Hal ini didukung dengan cara menempatkan figur wanita sebagai pimpinan humas Polda DIY dengan alasan bahwa wanita bisa membangun hubungan dengan cara yang lebih humanis dan kekeluargaan sebagai dasar dari komunikasi interpersonal untuk mengelola komunikasi dengan publik internal dan publik eksternal Polda DIY.

Penelitian dilakukan dengan tujuan utama untuk mengetahui Bidhumas Polda DIY menyikapi segala kritikan dan tudingan negatif dari masyarakat, penelitian ini dilakukan juga untuk mengetahui cara Bidhumas Polda DIY dalam mengelola infromasi-informasi yang dimiliki untuk disampaikan kepada publik internal dan publik eksternalnya, dan tujuan terakhir penelitian ini dilakukan adalah untuk mengetahui cara Polda DIY melalui Bidhumas menyikapi UU no.14 tahun 2006 tentang Keterbukaan Informasi Publik yang menuntut pihak Polda DIY harus terbuka dalam menyampaikan segala informasi yang dibutuhkan masyarakat. Hasil penelitian menemukan bahwa Polda DIY melalui Bidhumas sudah mengimplementasikan segala aturan-aturan yang ada pada UU no.14 tahun 2008 . Meskipun pada praktek di lapangan ditemukan kendala-kendala dalam mengimplementasikan UU tersebut, Bidhumas selalu berupaya melaksanakannya sebaik mungkin dan selalu melakukan evaluasi kinerja agar menjadi selalu lebih baik.

Salah satu faktor yang menunjukkan bahwa Bidhumas Polda DIY sudah bersikap terbuka sesuai dengan tuntutan dan aturan pada UU KIP tersebut adalah adanya publikasi rutin tahunan yaitu Laporan Akhir Tahun yang dipublikasikan kepada masyarakat Yogyakarta melalui acara Jumpa Pers AKhir Tahun. Laporan akhir tahun tersebut berisi sejumlah data-data terkait berbagai kasus dan peristiwa yang terjadi di seputaran wilayah 
Yogyakarta yang juga disertai data tentang proses tindak lanjut Polda DIY. Bidhumas Polda DIY berharap dengan adanya laporan tersebut publik internal dan eksternal Polda DIY tidak lagi berpikiran bahwa Polda DIY tidak menyelesaikan tugas-tugasnya sebagai pelayan, pengayom, dan pelindung masyarakat.

\section{E. SIMPULAN}

Penelitian ini dilakukan untuk memahami aktifitas peran Bidang Hubungan Masyarakat Kepolisian Daerah Daerah Istimewa Yogyakarta yang dilakukan untuk mengelola informasi terkait manajemen komunikasi publik. Berikut ini penjelasan kesimpulan dan saran yang dapat diambil dari penelitian ini.

\section{Kesimpulan}

Bidhumas Polda DIY dalam mengelola informasi yang ada dengan cara memanfaatka media. Media yang dimaksud dibedakan menjadi dua yaitu: pertama media dalam konteks sebagai alat bantu untuk menyampaikan pesan kepada publik internal dan publik eksternal Polda DIY. Media sebagai alat bantu ini pun dibedakan menjadi dua yaitu pertama media konvensional yaitu media yang cenderung satu arah karena dala mendapatkan respon dari publiknya membutuhkan waktu yang relatif lama. Media sebagai alat bantu yang kedua adalah media baru yaitu media yang cenderung dua arah karena proses pemberian dan penerimaan respon membutuhkan waktu yang relatif lebih cepat. Oleh karena itu pemanfaatan media baru ini disebut sebagai media yang interaktif, hal ini juga dikarenakan media baru menggunakan koneksi internet sebagai pendukung utamanya. Media kedua yang dimanfaatkan oleh Bidhumas Polda DIY adalah media dalam konteks alat lembaga pengelola pesan yang biasa disebut media pemberitaan atau bisa juga disebut pers jurnalis.

Melalui media massa, arah dan kebijakan pemerintah dapat tersalurkan dengan baik karena memiliki fungsi yang strategis dalam menyampaikan informasi. Dari pembahasan di atas, dapat ditarik suatu kesimpulan bahwa Bidang Humas telah melakukan kegiatan media relations dengan cukup baik. Dalam menjalankan fungsinya, Bagian Humas dan Informasi Pemerintah Kota Yogyakarta telah melakukan berbagai hal agar keharmonisan hubungan dengan media dapat terjaga. Kegiatan tersebut terbagi menjadi dua yaitu yang bersifat formal dan non formal. Pertama, aktivitas formal media relations di antaranya dengan melakukan press release, jumpa pers, kerjasama penulisan dengan media cetak, kerjasama dengan media elektronik dan mengadakan diskusi forum dengan pihakpihak tertentu yang bertujuan mewujudkan keamanan dan ketertiban di wilayah Daerah Istimewa Yogyakarta. Kedua, kegiatan yang bersifat non formal diantaranya berupa, personal relationship (hubungan personal) dengan berbagai elemen masyarakat dan kunjungan ke sekolah dalam pemberian edukasi seputar keamanan dan ketertiban.

\section{Saran}

Penulis mengharapkan petugas Bidhumas Polda DIY lebih peduli kepada media yaitu dengan mengetahui dan memahami keinginan, sikap, reaksi, hingga menampung aspirasi dari para jurnalis/wartawan. Misalnya berupa kotak saran yang ditempatkan di 
depan ruangan Kabidhumas Polda DIY, sehingga memudahkan jurnalis/wartawan yang ingin menyampaikan saran maupun kritik. Pihak Polda DIY diharapkan lebih tepat waktu pada saat kegiatan atau acara yang akan diselenggarakan, sehingga para wartawan tidak menunggu lama mengingat mereka harus bekerja untuk menunaikan tugas lain. Untuk lebih memudahkan jurnalis/wartawan menulis berita tentang kepolisian, maka pihak Bidhumas Polda DIY wajib menyiapkan naskah press release yang selanjutnya dibagikan kepada para jurnalis/wartawan. Hal tersebut dilakukan agar jurnalis/wartawan tidak salah dalam membuat tulisan artikel berita yang dipublikasikan kepada masyarakat umum melalui koran atau media lainnya sesuai jenis media pemberitaan masing-masing institusi media.

\section{DAFTAR PUSTAKA}

Arikunto. Suharsimi. 2002. Prosedur Penelitian Suatu Pendekatan Praktek. Rineka Cipta. Yogyakarta.

Arko K. Sukatendel. 1990. Public Relations Perusahaan. Fikom Unpad. Bandung.

Azwar. Saifuddin. 2003. Metode Penelitian. Pustaka Pelajar, Yogyakarta.

Bogdan and Biklen. 1982. Qualitative Research For Education. Toroto: Alyn and Bacon

Boulding Kenneth Ewart. 1956. The Image: Knowledge in Life and Society. Michigan. University of Michigan Press.

Burhan Bungin. 2004. Metode Penelitian Kualitatif. Jakarta: Raja Grafindo Persada.

Cutlip, Scott M, Center, Allen H\&Broom, Glen M. 2006. Effective Public Relations. Kencana. Jakarta.

Effendy. Onong Uchjana. 2001. Ilmu Komunikasi dan Praktek, PT Remaja Rosdakarya. Bandung.

Rachmadi. F. 1994. Public Relations Dalam Teori dan Praktek (Aplikasi dalam Badan Usaha

Swasta dan Lembaga Pemerintah). PT. Pustaka Utama. Jakarta.

Frida Kusumastuti. 2002. Dasar-dasar Humas. Ghalia Indonesia dan UMM Press. Jakarta. Goldhaber, Gerald M. 1990. Organizational Communication. Brown \& Benchmark.

Ibrahim Idi. 2010. Kecerdasan Komunikasi: Seni Berkomunikasi Kepada Publik. Simbiosa Rekatama Media. Jakarta.

Jefkin. Frank. 1996. Public Relations. Erlangga. Jakarta

Kriyantono. Rachmat. 2006. Teknik Praktis Riset Komunikasi. Kencana Prenada Group. Jakarta.

Moekijat. 1993. Teori Komunikasi. Mandar Maju. Jakarta.

Moleong. Lexy. 2006. Metode Penelitian Kualitatif. PT. Remaja Rosdakarya. Bandung.

Neuman. W Lawrence. 2000. Social Research Methods: Qualitative and Quantitative Approach $4^{\text {th }}$ Edition. Aviacom: Allyn \& Bacon. USA.

Onong Uchjana. Effendy M A. 1999. Hubungan Masyarakat, Suatu Studi Komunikologis. PT. Remaja Rosdakarya. Bandung.

Pace, Wayne\&Faules, Don f. 2000. Komunikasi Organisasi: Strategi Meningkatkan Kinerja Perusahaan. Remaja Rosdakarya. Bandung.

Ritonga. Jamiludin M. 2004. Riset Kehumasan. Grasindo. Jakarta.

152 Medi Trilaksono Dwi Abadi 
Robbins, Stephen P. 2003. Perilaku Organisasi $10^{\text {th }}$ Edition. Prentice Hall. New Jersey. Robbins, Stephen P. 2004. Budaya Korporat dan Keunggulan Korporasi. Elex Media Komputindo. Jakarta.

Ruslan, Rosady. 2005. Manajemen Public Relations dan Media Komunikasi: Konsep dan Aplikasinya. Rajawali Pers. Jakarta.

Soemirat, Soleh\&Ardianto, Elvinaro. 2004. Dasar-dasar Public Relations. Remaja Rosdakarya. Bandung.

Referensi online :

www.jogja.polri.go.id

www.polri.go.id

www.sindonews.com

www.krjogja.com

www.tribunjogja.com

www.harianjogja.com 
